\title{
The Big Five Personality Traits as Determinants of Teachers' Achievement Motivation
}

\author{
Biljana Mirković ${ }^{1}$ \\ Psychology Study Programme, Faculty of Philosophy, University of Banja Luka, Banja \\ Luka, Bosnia and Herzegovina \\ Ivana Zečević \\ Psychology Study Programme, Faculty of Philosophy, University of Banja Luka, Banja \\ Luka, Bosnia and Herzegovina \\ Nela Marinković \\ Psychology Study Programme, Faculty of Philosophy, University of Banja Luka, Banja \\ Luka, Bosnia and Herzegovina
}

\begin{abstract}
Many studies have reported that motivated teachers put more effort in order to affect the behaviour of their students in the most desirable and positive manner and to transfer appropriate knowledge to their students. The objective of this study was to determine if the Big Five personality traits predict the achievement motive for teachers' work. The sample consisted of 732 teachers $(75.4 \%$ female) from 25 Bosnia and Herzegovina elementary schools, and the Big Five Inventory and Achievement Motive Scale were used. The results of Regression Analysis show that personality traits explain $31 \%$ of the variance of the achievement motive total score. When it comes to components of the achievement motive, the Big Five personality traits explain $8 \%$ of the variance in competition with other people, $49 \%$ of the variance in persistence in goal achieving, $34 \%$ of the variance in goal achievement as a source of satisfaction, and $18 \%$ of the variance in orientation towards planning. Conscientiousness is the most powerful predictor of all components of the achievement motive, as well as of the achievement motive total score. Extraversion and openness are significant positive predictors of the following components: competition with other people, persistence in goal achieving and goal achievement as a source of satisfaction, and the total score for the achievement motive. Finally, the obtained results show that teachers' achievement motive has a significant personal background.
\end{abstract}

Keywords: teachers, achievement motive, personality traits.

\section{Introduction}

Teachers play an important role in the academic performance and the growing up of children. Many studies (e.g. Azubuike \& Oko, 2016; Joshua \& Lang, 2004; Corcoran, Evans, $\&$ Schwab, 2004) have reported a significant impact of teacher motivation on students' ac-

1 biljana.mirkovic@ff.unibl.org 
ademic achievement. Motivated teachers put more effort in order to affect the behaviour of their students in the most desirable and positive manner and to transfer appropriate knowledge to their students (Joshua \& Lang, 2004). Motivated teachers can impact students' academic achievements by helping them to explore and develop their cognitive, psychomotor and affective predispositions (Azubuike \& Oko, 2016).

The importance of achievement motives for productive teacher behaviour is best observed from the mindset and behaviour of individuals who have developed the achievement motive, which actually implies: wanting the problem solved, clearly defining goals and dealing with the problem, thinking about the actions that can be taken to achieve the goal, and anticipating the difficulties that may be encountered on the way to achieving a goal or solving a problem (Franceško \& Mirković, 2008). Therefore, this complex motivational disposition is a significant factor of success for teachers. The achievement motive positively contributes to the successful implementation of teachers' activities and roles in a twofold sense, i.e. those professional roles strictly related to teaching, but also those in a more general sense, such as the development of students' motivation, which is also significant (Trebješanin, 1998). Individuals who have developed the achievement motive are realistic when it comes to the selection of tasks (they do not select easy tasks, but neither do they choose extremely difficult ones), they are more successful in achieving long-term goals and in performing long-lasting activities, and they can clearly set up tasks and goals, and be more specific and precise in defining criteria for success (Rot, 2006). However, there are very few papers dealing with the determinants of teachers' achievement motive.

The achievement motive in literature is described as a relatively permanent disposition whose core consists of a more or less expressed need for competence, i.e. being successful in situations when a certain level of success has to be reached or exceeded (Rheinberg, 2004). According to McClelland (McClelland, Atkinson, Clark, \& Lowell, 1953) this complex motivational disposition contains two components: a personal tendency to set up a goal and competition with others. Subsequent studies conducted by Franceško and colleagues (Franceško, Kodžopeljić, \& Mihić, 2002a; Franceško, Mihić, \& Bala, 2002b) indicate that the achievement motive consists of four components: (1) Competition with others, (2) Goal achievement as a source of satisfaction, (3) Persistence in goal achieving, and (4) Orientation towards planning. These authors conclude that their findings support McClelland's concept that there are two basic components of the achievement motive: making efforts to achieve what is considered valuable - setting up goals, and making oneself prominent - competition with others. The other two separated components are instrumental traits or behaviour forms developed by a person in order to be successful when competing with others and/or achieving goals. Competition with others is a person's tendency to stand out and be more successful than others and is an extrinsic component of the achievement motive. Goal achievement as a source of satisfaction is a tendency to set goals whose achievement is perceived as a reward and is an intrinsic component of the achievement motive. Instrumental behaviour for achieving success is Persistence in goal achievement, which indicates persistence in the pursuit of a goal, and the Orientation towards planning, which represents the tendency to plan activities in order to achieve a specific goal (Franceško et al., 2002a; Franceško et al., 2002b). These findings have been confirmed by several studies (Arsenijević-Puhalo \& Puhalo, 2006; Mihić, ŠakotićKurbalija, \& Franceško, 2005). According to the study conducted by Franceško et al. (2002a), differences in the structure of the achievement motive indicate whether a person has a desire 
for achievement, and the necessary skills to become successful. Furthermore, the authors explain that if a person has a tendency to compete, but has not developed the skills of perseverance and orientation towards planning, he/she is unlikely to be successful. The achievement motive is responsible for advancing at personal, organizational and social levels. People with high levels of achievement motivation set themselves very high-performance standards (Franceško et al., 2002a; McClelland et al., 1953).

The Five-Factor Model of Personality (McCrae \& Costa, 1990) assumes that the space of the basic personality structure can be described along five broad dimensions: Extraversion, Conscientiousness, Agreeableness, Openness to Experience and Neuroticism. Results of previous studies showed that the personality traits of teachers have a significant impact on the relationship with students, which influences the success of teaching (Jong, Mainhard, Tartwijk, Veldman, Verloop, \& Wubbels, 2013). Also, studies (Busato, Prins, Elshout, \& Hamaker, 2000; Dweck \& Leggett, 1988; Hart, Stasson, Mahoney, \& Story, 2007; Kaiser \& Ozer, 1994; Komarraju, Karau, \& Schmeck, 2009; Sharma, 2013; Sharma, Bottom, \& Elfenbein, 2013; Poropat, 2009) have shown that there is a significant correlation between the Big Five personality traits and the achievement motive. Studies have shown that the achievement motive is positively correlated with conscientiousness and extraversion, and negatively with neuroticism (Busato et al. 2000; Dweck \& Leggett, 1988; Hart et al., 2007; Kaiser \& Ozer, 1994; Komarraju et al., 2009; Sharma, 2013; Sharma et al., 2013; Poropat, 2009). Studies also showed a negative correlation between agreeableness and the achievement motive (Hart et al., 2007), and a positive correlation between openness to experience and the achievement motive (Dweck \& Leggett, 1988).

Considering that the achievement motive is in a significant relationship with the Big Five personality traits (e.g. Dweck \& Leggett, 1988; Hart et al., 2007; Kaiser \& Ozer, 1994; Poropat, 2009), the aim of this study was to examine how much teachers' achievement motive can be explained by Big Five personality traits. We expect the Big Five personality traits to have an impact on teachers' achievement motive. The achievement motive, by its nature, is classified as a social motive (McClelland et al., 1953). Social factors, such as family, culture, social values, etc. affect the level of the achievement motive. However, some authors, such as Rheinberg, argue that the achievement motive is a relatively permanent disposition and significantly determined by personality structure (Rheinberg, 2004). Knowledge about the role of the Big Five personality traits in the teachers' achievement motive can be useful in developing and promoting the achievement motive in the teacher population, and contribute to a better understanding of teacher motivation as a whole.

\section{Methods}

\section{Sample and procedure of data collection}

The sample was composed of 732 teachers (75.4\% female) from 25 Bosnia and Herzegovina elementary schools. As for the location of the schools, $63.8 \%$ of schools werelocated in cities, $10.2 \%$ in the suburbs, and $26 \%$ in villages. Class teachers participated in this study with $46 \%$ and subject teachers with $54 \%$. The sample was divided into five age cohorts: up 
to 25 years ( $4.2 \%), 26-35$ years ( $28.7 \%), 36-45$ years (36.9\%), $46-55$ years $(20.6 \%)$ and over 56 years $(9.6 \%)$. In terms of the length of service, the sample was divided into four cohorts: up to 5 years of service (20.8\%), 6-15 years (38.1\%), 16-25 (26.5\%) and over 26 years (14.6\%). In terms of socioeconomic status, the sample was divided into four cohorts: below average (8.3\%), average (82.7\%) and above average (9\%).

The research was conducted in the period from October 2017 to December 2018. Data were collected in schools using a paper-and-pencil format, under the supervision of the researchers. The participants filled out the questionnaire in groups. The respondents needed approximately 30 minutes to complete it. Participation was voluntary.

\section{Instruments}

The following instruments were used:

The Achievement Motive Scale - MOP2002 (Franceško et al., 2002b); The scale consists of 55 items distributed in four sub-scales that measure components of the achievement motive: Competition with others (e.g. It is important for me to stand out with my success.), Persistence in goal achieving (e.g. I always persist in achieving my goal.), Goal achievement as a source of satisfaction (e.g. Successful work is the biggest reward for me.), and Orientation towards planning (e.g. I plan everything in advance to achieve better results.). The participants' task was to express the degree of agreement with each item with their job in mind. The participants' responses to the MOP2002 are given on a 5-point Likert type scale from 1 (1 - strongly disagree) to 5 (5 - strongly agree). The score is formed as a linear combination of estimates on all items which make up the subscale. For this study, Cronbach's alpha was .91 for Competition with others, .83 for Persistence in goal achieving, .87 for Goal achievement as a source of satisfaction, .73 for Orientation towards planning, and .93 for the whole scale.

The Big Five Inventory - BFI (John, Donahue, \& Kentle, 1991); The questionnaire contains 44 items distributed in five sub-scales that measure personality traits: Extraversion (e.g. I see myself as someone who is talkative.), Agreeableness (e.g. I see myself as someone who is helpful to others and unselfish.), Conscientiousness (e.g. I see myself as someone who does a thorough job.), Neuroticism (e.g. I see myself as someone who can be tense.), and Openness to experience (e.g. I see myself as someone who is curious about many different things.). The items are formulated as short phrases based on the adjectives of traits that are the prototypes of the Big Five model. The participants' responses to the BFI are given on a 5-point Likert type scale from 1 (1 - strongly disagree) to 5 (5 - strongly agree). The score is formed as a linear combination of estimates on all items which make up the subscale. For this study, Cronbach's alpha was .76 for Extraversion, .65 for Agreeableness, .82 for Conscientiousness, .71 for Neuroticism, and .80 for Openness to experience.

The Socio-Demographic Checklist consisted of six questions about the following demographic characteristics: gender, age, length of service, position, placement of the school, and material status.

\section{Data Analyses Techniques}

The following statistical procedures were used for data analysis: descriptive statistics, correlation analysis, and regression analysis. Data analysis was performed using the statistical software package SPSS for Windows, version 20.0. 


\section{Results}

Table 1 presents the descriptive statistical measures for the variables used in the study. Measures of average and variability, skewness and kurtosis for the Achievement Motive Scale and Big Five Inventory do not indicate major distribution deviations compared to a normal distribution (Tabachnick \& Fidell, 2001).

Analysis of correlations between the components of the achievement motive (Table 1) shows that all relations are significant and positive $(.22<r<.72)$. Considering the correlations between the Big Five personality traits and the achievement motive, we can see that extraversion, agreeableness, conscientiousness, and openness to experience are significantly positively correlated, while neuroticism significantly negatively correlates with the achievement motive and its components (only a component of the achievement motive, namely, competition with others, is not significantly correlated with agreeableness and neuroticism). The achievement motive and its four components have the highest positive correlation with conscientiousness $(.18<r<.67)$.

Table 1

Descriptive statistics and correlations between the examined variables

\begin{tabular}{cccccccccc}
\hline & & & & & & & & \multicolumn{5}{c}{ Correlations } \\
\cline { 7 - 10 } COP & 56.36 & 12.85 & -.00 & -.10 & 1.00 & & & \\
PGA & 61.21 & 6.92 & -.37 & .31 & $.22^{* * *}$ & 1.00 & & & \\
GAS & 53.87 & 6.53 & -.74 & 1.43 & $.44^{* * *}$ & $.72^{* * *}$ & 1.00 & & \\
OTP & 28.58 & 4.84 & -.34 & .38 & $.32^{* * *}$ & $.54^{* * *}$ & $.57^{* * *}$ & 1.00 & \\
TAM & 200.33 & 23.80 & -.14 & .53 & $.79^{* * *}$ & $.72^{* * *}$ & $.84^{* * *}$ & $.69^{* * *}$ & 1.00 \\
E & 29.42 & 4.89 & -.07 & -.23 & $.20^{* * *}$ & $.36^{* * *}$ & $.32^{* * *}$ & $.14^{* * *}$ & $.34^{* * *}$ \\
A & 35.45 & 4.35 & -.32 & .06 & .03 & $.36^{* * *}$ & $.29^{* * *}$ & $.16^{* * *}$ & $.24^{* * *}$ \\
C & 36.60 & 4.93 & -.38 & -.28 & $.18^{* * *}$ & $.67^{* * *}$ & $.53^{* * *}$ & $.42^{* * *}$ & $.52^{* * *}$ \\
N & 20.75 & 4.46 & .11 & .45 & -.07 & $-.27^{* * *}$ & $-.19^{* * *}$ & $-.12^{* *}$ & $-.21^{* * *}$ \\
O & 37.02 & 5.43 & -.10 & -.01 & $.23^{* * *}$ & $.42^{* * *}$ & $.39^{* * *}$ & $.13^{* * *}$ & $.38^{* * *}$ \\
\hline
\end{tabular}

Note. COP - Competition with other people; PGA - Persistence in goal achieving; GAS - Goal achievement as a source of satisfaction; OTP - Orientation towards planning; TAM - Total score on the achievement motive scale; E - Extraversion; A -Agreeableness; C - Conscientiousness; N - Neuroticism; O - Openness to experience.

${ }^{* *} p<.01,{ }^{* * *} p<.001$

In order to determine the particular contribution of the Big Five personality traits to the explanation of the achievement motive, regression analysis was conducted, and the results are shown in Table 2. 
Table 2

The predictive contribution of the Big Five personality traits to the achievement motive

\begin{tabular}{lccccc}
\hline & COP & PGA & GAS & OTP & TAM \\
\cline { 2 - 6 } & $\beta$ & $\beta$ & $\beta$ & $\beta$ & $\beta$ \\
\cline { 2 - 6 } Extraversion & $.12^{* *}$ & $.08^{*}$ & $.10^{* *}$ & -.01 & $.11^{* * *}$ \\
Agreeableness & -.08 & .04 & .04 & -.03 & -.03 \\
Conscientiousness & $.12^{* *}$ & $.55^{* * *}$ & $.42^{* * *}$ & $.46^{* * *}$ & $.42^{* * *}$ \\
Neuroticism & .01 & -.02 & .04 & .02 & -.00 \\
Openness & $.16^{* * *}$ & $.16^{* * *}$ & $.19^{* * *}$ & -.03 & $.18^{* * *}$ \\
\hline$R^{2}$ & .08 & .49 & .34 & .18 & .31 \\
$F$ & $11.12^{* * *}$ & $130.40^{* * *}$ & $70.03^{* * *}$ & $30.75^{* * *}$ & $64.68^{* * *}$ \\
\hline
\end{tabular}

Note. COP - Competition with other people; PGA - Persistence in goal achieving; GAS - Goal achievement as a source of satisfaction; OTP - Orientation towards planning; TAM - Total score on the achievement motive scale ${ }^{*} p<.05,{ }^{* *} p<.01,{ }^{* * *} p<.001$

The obtained results (Table 2) show that the Big Five personality traits have substantial predictive power for the total score of the achievement motive (explained $31 \%$ of the variance). By observing the components of the achievement motive, it can be seen that the Big Five personality traits have weak predictive power for competition with other people (explained $8 \%$ of the variance), moderate predictive power for orientation towards planning (explained $18 \%$ of the variance), and substantial predictive power for persistence in goal achieving (explained $49 \%$ of the variance) and goal achievement as a source of satisfaction (explained $34 \%$ of the variance). Conscientiousness is the most powerful predictor $(.12<\beta<.55)$ of all components of the achievement motive and the total achievement motive score. Openness and extraversion are significant positive predictors of the following components: competition with other people, persistence in goal achieving and goal achievement as a source of satisfaction, and the total score achievement motive score. Openness is a slightly stronger predictor $(.16<\beta<.19)$ than extraversion $(.08<\beta<.12)$.

\section{Discussion}

The aim of this study was to examine the contributions of the Big Five personality traits in explaining the teachers' achievement motive. The obtained results showed that the Big Five personality traits represent significant determinants of the teachers' achievement motive. The effect of the Big Five personality traits on the total score for the achievement motive is substantial. When it comes to components of the achievement motive, the effect of the Big Five personality traits on persistence in goal achieving and goal achievement as the source of satisfaction is, also, substantial. In the case of orientation towards planning, the effect of the Big Five personality traits is moderate and weak for competition with other people. These results are consistent with the view that the achievement motive is a relatively permanent disposition and significantly determined by personality structure (Rheinberg, 2004). 
Conscientiousness proved to be the most powerful positive predictor of the total score for the achievement motive and all components of the achievement motive. The results of some previous studies (e.g. Busato et al., 2000; Dweck \& Leggett, 1988; Hart et al., 2007; Kaiser \& Ozer, 1994; Komarraju et al., 2009; Poropat, 2009; Sharma, 2013; Sharma et al., 2013) also showed that conscientiousness has the highest positive correlation with the achievement motive. We can assume that the ability of self-control in the sense of a self-disciplined tendency towards goals and strict adherence to one's own principles, which is the basis of conscientiousness (John \& Srivastava, 1999; McCrae \& Costa, 1990; Organ \& Lingl, 1995), helps a teacher to be persistent in achieving goals. Namely, selfdiscipline brings organization, structure, and engagement in terms of planning, setting, and achieving goals.

Extraversion and openness also proved to be significant positive predictors of the achievement motive total score, and its components: competition with other people, persistence in goal achieving and goal achievement as a source of satisfaction. Some other authors have also found a positive relationship between extraversion and the achievement motive, in a sample of students (Komarraju et al., 2013) and in a corporate environment (Busato et al., 2000). Having in mind that extraversion includes activity, entrepreneurship, ambitiousness, assertiveness, enthusiasm, energy, and firmness (John \& Srivastava, 1999; McCrae \& Costa, 1990), the obtained result is not surprising. Namely, extraversion directs us to others and thanks to it we position ourselves in the group and tend to compete with others. These features also help the teacher persist in goal achievement.

Hart et al. (2007) also pointed to the positive connection between openness to experience and the achievement motive in a sample of students. The study conducted by Dweck and Leggett (Dweck \& Leggett, 1988) indicated a positive relationship between openness to experience and the achievement motive in a corporate environment. It is not surprising that openness to experience is inspirational for the achievement motive in teachers because as much as they try to plan their teaching in detail, the process of learning and teaching is always full of surprises, so for successful implementation, it is necessary to have a dose of creativity and imagination. People who are open to new experiences are more goal-oriented, persistent, and willing to seek different solutions in the process of achieving those goals. The obstacles on the way will not stop them easily.

\section{Conclusion and implications}

The results of this study have shown that the Big Five personality traits determine the achievement motive in teachers. Conscientiousness is the most powerful predictor of the achievement motive, followed by openness and extraversion. These results have theoretical and practical significance. First, although the achievement motive is classified as a social motive, which implies that it is largely determined by social factors, our results show that teachers' achievement motive has a significant personal background. Second, knowledge of personality traits can make it easier to assess the teacher's desire for achievement, and in that way help in the selection of teachers with a better predisposition for successful teaching. Third, the obtained findings could be useful in the 
preparation of professional support programs for teachers, which can help them acquire the necessary skills and competencies for the job, such as self-discipline, goal orientation, persistence in goal achievement, commitment to the task, planning orientation, creativity, entrepreneurship, etc., thus contributing to the development of the overall achievement motive in teachers.

In the end, it is important to note that this study has several limitations. First, convenience sampling was used, meaning the respondents were teachers willing to participate in the study. It is possible that the differences in terms of socio-demographic characteristics in relation to the population of teachers in Bosnia and Herzegovina have not been completely verified, which reduces the possibility of drawing general conclusions. The goal of further studies of this type will be to include a more representative sample. Second, considering that all data were collected from the same sources in the same time period, through self-assessment done by respondents, there is a possibility of the effect of "common method bias" (Podsakoff, MacKenzie, Lee, \& Podsakoff, 2003). In order to prevent this problem in future research, data on predictor and criterion variables should be collected from different sources, in this case, from supervisors and students. Also, it is necessary to introduce a time difference between the measurement of predictor and criterion variables. Third, factors of the achievement motive also include value orientations, the parameters of existential fulfillment, self-actualization, selfefficacy, self-concept, etc. (e.g. Clipa \& Greciuc, 2018; Huan \& Lu, 2017; Whiteside, 1978; Rezaei, Ahadi, \& Asadzadeh, 2015), which were not included in this research. Therefore, future research should examine their contribution to teachers' achievement motive. Such research could encourage empirically-based interventions to promote the achievement motive of teachers. However, the indicated limitations do not diminish the significance of the obtained results which suggest the importance of personality traits for teachers' achievement motive.

\section{References}

Arsenijević-Puhalo, A., \& Puhalo, S. (2006). Motiv postignuća menadžerki i menadžera u Banja Luci i Sarajevu. In B. Kuzmaović and Z. Krnjaić (Eds.), Zbornik radova Empirijska istraživanja u psihologiji (pp. 227-234). Beograd: Institut za psihologiju.

Azubuike, K. A., \& Oko, O. F. (2016). Impact of teachers' motivation on the academic performance of students: Implications for school administration. National Journal of Educational Leadership, 3, 91-99.

Busato, V. V., Prins, F. J., Elshout, J. J., \& Hamaker, C. (2000). Intellectual ability, learning style, personality, achievement motivation and academic success of psychology students in higher education. Personality and Individual Differences, 29(6), 1057-1068. https://doi.org/10.1016/ S0191-8869(99)00253-6 
Clipa, O., \& Greciuc, M. A. (2018). Relations of Style of Leadership and Achievement Motivation for Teacher. Revista Romaneascapentru Educatie Multidimensionala, 10(4), 112-118. https://doi. org/10.18662/rrem/72

Cohen, J. (1988). Statistical power analysis for the behavioral sciences (2nd Edition). Hillsdale, NJ: Erlbaum.

Corcoran, S. P., Evans, W. N., \& Schwab, R. M. (2004). Changing Labor-Market Opportunities for Women and the Quality of Teachers, 1957-2000. American Economic Review, 94(2), 230-235. https://doi. org/10.1257/0002828041301920

Dweck, C. S., \& Leggett, E. L. (1988). A social-cognitive approach to motivation and personality. Psychological Review, 95(2), 256-273. https://doi.org/10.1037/0033-295X.95.2.256

Franceško, M., Kodžopeljić, J., \& Mihić, V. (2002a). Neki socio-demografski i psihološki korelati motiva postignuća. Psihologija, 35(1-2), 65-79.

Franceško, M., Mihić, V., \& Bala, G. (2002b). Struktura motiva postignuća merena skalom MOP2002. In B. Čukić and M. Franceško (Eds.), Ličnost u višekulturnom društvu - Zbornik odseka za psihologiju Filozofskog fakulteta u Novom Sadu (pp.134-143). Novi Sad: Filozofski fakultet.

Franceško M., \& Mirković, B. (2008). Organizaciono ponašanje: moć poznavanja organizacionog ponašanja. Novi Sad: USEE i Prometej.

Hart, J. W., Stasson, M. F., Mahoney, J. M., \& Story, P. (2007). The Big Five and Achievement Motivation: Exploring the Relationship Between Personality and a Two-Factor Model of Motivation. Individual Differences Research, 5(4), 267-274.

Huan, J., \& Lu, Q. (2018). A Correlation Study among Achievement Motivation, Goal-Setting and L2 Learning Strategy in EFL Context. English Language Teaching, 11(2), 5-14. https://doi.org/10.5539/ elt.v11n2p5

John, O. P., Donahue, E. M., \& Kentle, R. L. (1991). The Big Five Inventory-Versions 4a and 54. Berkeley, CA: University of California, Berkeley, Institute of Personality and Social Research.

John, O. P., \& Srivastava, S. (1999). The Big Five Trait taxonomy: History, measurement, and theoretical perspectives. In L. A. Pervin, \& O. P. John (Eds.), Handbook of personality: Theory and research (pp. 102-138). New York: Guilford Press.

Jong, R., Mainhard, T., Tartwijk, J., Veldman, I., Verloop, N., \& Wubbels, T. (2013). How pre-service teachers' personality traits, self-efficacy, and discipline strategies contribute to the teacher-student relationship. British Journal of Educational Psychology, 84(2), 294-310. https://doi.org/10.1111/ bjep. 12025

Joshua, A. D., \& Lang, K. (2004). Does School Integration Generate Peer Effects? Evidence from Boston's Metco Program. American Economic Review, 94(5), 1613-1634. https://doi.org/10.1257/ 0002828043052169

Kaiser, R. T., \& Ozer, D. J. (1997). Emotional stability and goal-related stress. Personality and Individual Differences, 22(3), 371-379. https://doi.org/10.1016/S0191-8869(96)00208-5

Komarraju, M., Karau, S. J., \& Schmeck, R. R. (2009). Role of the Big Five Personality Traits in Predicting College Students' Academic Motivation and Achievement. Learning and Individual Differences, 19(1), 47-52. https://doi.org/10.1016/j.lindif.2008.07.001

McClelland, D. C., Atkinson, J. W., Clark, R. A., \& Lowell, E. L. (1953). Century psychology series. The achievement motive. Appleton-Century-Crofts. https://doi.org/10.1037/11144-000

McCrae. R. R., \& Costa, P. T. Jr. (1990). Personality in adulthood. New York: Guilford. 
Mihić, V., Šakotić-Kurbalija, J. M., \& Franceško, M. (2005). Achievement motive and locus of control as motivation factors of European identity. Psihologija, 38(4), 445-459.

Organ, D. W., \& Lingl, A. (1995). Personality, satisfaction, and organizational citizenship behavior. The journal of social psychology, 135(3), 339-350. https://doi.org/10.1080/00224545.1995.9713963

Poropat, A. E. (2009). A meta-analysis of the five-factor model of personality and academic performance. Psychological Bulletin, 135(2), 322-338. https://doi.org/10.1037/a0014996

Podsakoff, P. M., MacKenzie, S. B., Lee, J. Y., \& Podsakoff, N. P. (2003). Common method biases in behavioral research: a critical review of the literature and recommended remedies. Journal of applied psychology, 88(5), 879-903. https://doi.org/10.1037/0021-9010.88.5.879

Rheinberg, F. (2004). Motivationsdiagnostik. Goettingen: Hogrefe.

Rezaei, L., Ahadi, H., \& Asadzadeh, H. (2015). Providing a causal model for motivating achievement based on the dimensions of self-efficacy-based learning model. Journal of Psychological Models and Methods, 20(6), 1-15.

Rot, N. (2006). Osnovi socijalne psihologije. Beograd: Zavod za udžbenike i nastavna sredstva.

Sharma, E. (2013). Personality Mapping: Tool to Analyse Achievement Orientation. iBusiness, 5(2), 59-64. https://doi.org/10.4236/ib.2013.52007

Sharma, S., Bottom, W. P., \& Elfenbein, H. A. (2013). On the role of personality, cognitive ability, and emotional intelligence in predicting negotiation outcomes: A meta-analysis. Organizational Psychology Review, 3(4), 293-336. https://doi.org/10.1177/2041386613505857

Tabachnick, B. G., \& Fidell, L. S. (2001). Using Multivariate Statistics (4th Edition). Boston: Allyn and Bacon.

Trebješanin, B. (1998). Intrinzička motivacija kao cilj nastavnog procesa, Zbornik Instituta za pedagoška istraživanja, 30, 168-184. Beograd: Institut za pedagoška istraživanja.

Примљено: 07.12.2019. Коригована верзија примљена: 01.06.2020. Прихваћено за штампу: 10.06.2020. 


\title{
Особине личности модела Великих пет као детерминанте мотива постигнућа наставника
}

\author{
Биљана Мирковић \\ Катедра за психологију, Филозофски факултет, Универзитет у Бањој Луци, \\ Бања Лука, Босна и Херцеговина \\ Ивана Зечевић \\ Катедра за психологију, Филозофски факултет, Универзитет у Бањој Луци, \\ Бања Лука, Босна и Херцеговина \\ Нела Маринковић \\ Катедра за психологију, Филозофски факултет, Универзитет у Бањој Луци, \\ Бања Лука, Босна и Херцеговина
}

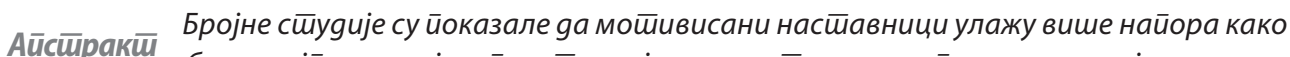
би на најӣожељнији и ӣозитиивнији начин уйицали на йонашање својих ученика

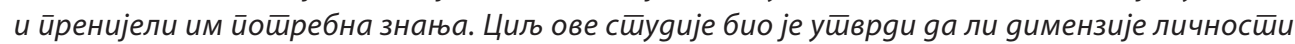

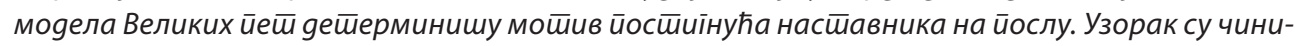
ла 732 насшиавника $(75,4 \%$ жене) из 25 основних школа у Босни и Херцеївини. Коришћени су

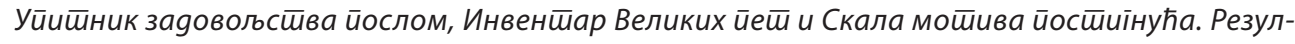

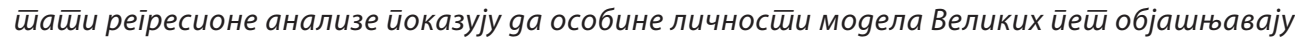

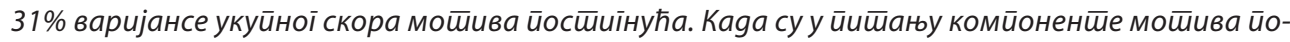
сйиїнућа, особине објашњавају 8\% варијансе шеакмичења са друїим љуgима, 49\% варијансе

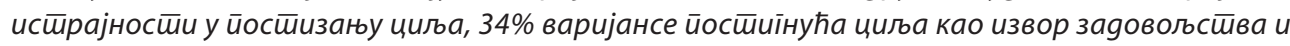

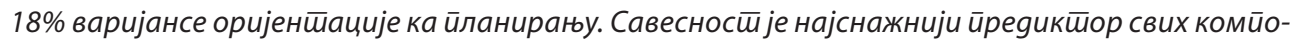

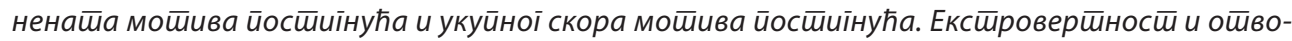

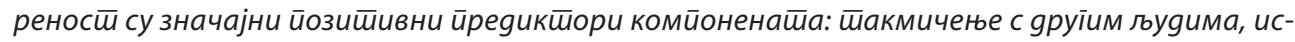

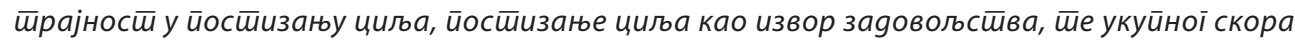

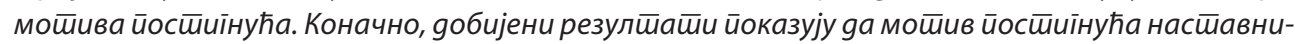
ка има значајно йерсонално йоријекло.
\end{abstract}

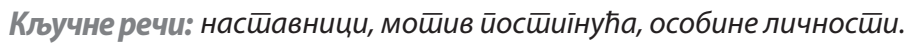




\title{
Качества личности модели Большой Пятерки как детерминанты мотивов достижения учителей
}

\author{
Биляна Миркович \\ Кафедра психологии, Философский факультет, Университет в Баня-Луке, \\ Баня-Лука, Босния и Герцеговина \\ Ивана Зечевич \\ Кафедра психологии, Философский факультет, Университет в Баня-Луке, \\ Баня-Лука, Босния и Герцеговина

\section{Нела Маринкович} \\ Кафедра психологии, Философский факультет, Университет в Баня-Луке, \\ Баня-Лука, Босния и Герцеговина
}

\begin{abstract}
Резюме Многочисленные исследования показали, что мотивированные учителя прилагают больше усилий, чтобы влиять на поведение учеников наиболее желательным и положительным образом и передавать им необходимые знания. Данное исследование проведено с целью, чтобы показать, определяют ли личностные параметры модели Большой пятерки мотив достижения учителей на работе. Исследование проведено на примере 732 учителей (75,4\% женшин) из 25 начальных школ Боснии и Гериеговины. Использовались Анкета удовлетворенности работой, Инвентарь Большой пятерки и Шкала мотивации достижений. Результаты регрессионного анализа показывают, что личностные черты модели «большой пятерки» объясняют 31\% дисперсии в общей оченке мотива достижения. Когда дело доходит до компонентов мотивов достижения, качества личности объясняют 8\% дисперсии соревнования с другими людьми, 49\% дисперсии настойчивости в достижении чели, 34\% дисперсии достижения цели как источника удовлетворения и 18\% дисперсии ориентации на планирование. Добросовестность - самый сильный предиктор всех компонентов мотива достижения и общей оченки мотива достижения. Экстраверсия и открытость являются важными положительными предикторами компонентов таких как: соревнование с другими, настойчивость в достижении цели, достижение чели как источника удовлетворения и общей оценки мотивов достижения. Полученные результаты показывают, что мотив достижения имеет существенное личностное происхождение.
\end{abstract}

Ключевые слова: учителя, мотив достижения, личностные качества. 